\title{
STUDI VISUAL KARAKTER DAN GESTUR CLIMOMANIA SEBAGAI PENDUKUNG PERANCANGAN ANIMASI PENDEK
}

\author{
M Rifqi Raynaldi ${ }^{1)}$, Frans santoso ${ }^{2)}$ \\ School of Design-Animation, Binus University \\ peredax@binus.ac.id
}

\begin{abstract}
Abstrak
Penelitian ini bertujuan untuk mengetahui penyakit gangguan sikologis Climomania yang meliputi gerak, kegiatan sehari-hari dan penyebab seorang bisa terkena Climomania. Dan penelitian ini menggunakan metode kualitatif dengan kunsultasi atau wawancara kepada seorang psikologi sehingga bisa mendapatkan informasi yang deskriptif, penulis juga mencari beberapa artikel dan buku psikologi terkait Climomania. Yang kemudian diolah ke dalam teori 12 prinsip gerak animasi dan beberapa feferensi sebagai penentuan konsep yang akan dibuat untuk pembuatan animasi pendek.
\end{abstract}

Kata Kunci: tema, gerakan, perilaku, animasi pendek

\begin{abstract}
The purposed of research was to know diseases psychological disorders of clinomania which includes motion, life style and causes a person to be affected by Clinomania. And this research uses qualitative method with consultation or interview to a psychologist so that can get descriptive information, the author also looks for some Clinomania related articles and psychology books. Which is then processed into the theory of 12 principles of motion animation and some reference as the determination of the concept that will be made for making short animation.
\end{abstract}

Keywords: tema, gesture, behaviour, short animation

Correspondence author: M Rifqi Raynaldi, peredax@binus.ac.id, Jakarta, and Indonesia (c) (i) 8

This work is licensed under a CC-BY-NC

\section{PENDAHULUAN}

Gangguan mental adalah suatu keadaan di mana fungsi mental sesorang mengalami disfungsi. Gangguan mental ialah hal-hal yang menyebabkan keditakwarasan atau ketidakwajaran terhadap kesehatan mental atau jiwa. Dalam terminologi yang lain gangguan mental ialah, adanya ketidakseimbangan yang terjadi pada diri kita, berpusat pada perasaan, emosional dan dorongan (motif/nafsu), yang mengakibatkan ketidakharmonisan pada fungsi-fungsi jiwa, yang menyebabkan kehilangan daya tahan jiwa, pada akhirnya jiwa menjadi labil dan cenderung mudah 
terpengaruh pada hal-hal negatif serta dirinya tidak mampu merasakan kebahagiaan serta tidak mampu mengaktualisasikan potensi-potensi yang ada dalam dirinya secara wajar.

Salah satunya dari jenis gangguan jiwa ialah clinomania, yang merupakan gangguan jiwa yang terobsesi pada tempat tidur (malas). Tema ini menjadi menarik jika menjadi sebuah film animasi pendek yang bisa menyampaikan informasi/pesan menjadi menarik. Dengan penyampaian melalui gesture dan karakter dari gangguan jiwa tersebut.

\section{Tinjauan Pustaka}

Sejarah Clinomania

Clinomania terdiri dari dua kata yaitu clin dan mania. Clin sendiri berasal dari bahasa Yunani yang berarti "tempat tidur" dan mania berarti "kecanduan" atau "terobsesi". Jadi, clinomania adalah terobsesi pada tempat tidur yaitu ingin selalu berada di atas kasur atau ranjang. Obsesi pada tempat tidur tidak berarti seseorang selalu tidur, tetapi ia selalu ingin berada di tempat tidur walaupun sambil melakukan pekerjaan. Orang-orang yang mengalami clinomania ini sebenarnya sedang mengalami masalah psikologis, sehingga dianjurkan untuk segera pergi ke psikolog untuk berkonsultasi. Obsesi pada tempat tidur menimbulkan rasa malas atau perasaan mengantuk terus-menerus yang mengakibatkan seseorang tidak ingin pergi melakukan kegiatan atau bekerja (Kenali gejala clinomonia, 2017).

\section{Teori Animasi}

Kata animate berasal dari kata kerja Latin animare,yang berarti "membuat jadi hidup atau mengisi dengan nafas". Pada animasi kita benar-benar bisa merestrukturisasi realitas (Wright, 2005:1). Pengertian secara umum, animate memiliki arti "memberi kehidupan kepada" dan termasuk juga live-action (gerakan langsung) pedalangan /pewayangan /permainan boneka semisal Sesame Street serta penggunaan peralatan electromechanical untuk menggerakkan boneka, dinamakan animatronics (Rick Parent 2010:6 dalam Prayoga, 2015). Animasi adalah animasi, apa pun medianya. Apakah menggambar di atas kertas, pemodelan dengan plastik/malam, mendorong beberapa kotak korek api di sekitar di depan kamera Bolex atau menganimasikan dengan komputer, untuk menjadi seorang animator akan perlu memahami gerakan dan cara membuat emosi (Shaw, 2012). Modal utama seorang animator adalah kemampuan menangkap momentum ke dalam runtutan gambar sehingga seolah-olah menjadi bergerak atau hidup. Sedikit berbeda dengan komikus, ilustrator, atau -katakanlah- karikaturis yang menangkap suatu momentum ke dalam sebuah gambar diam (still). Animator harus lebih memiliki 'kepekaan gerak' daripada 'hanya' sekadar kemampuan menggambar. Gambar yang bagus akan percuma tanpa didukung kemampuan menghidupkan. Sebagaimana definisi dasar animasi yang berarti: membuat seolah-olah menjadi hidup. Dalam buku Illusion of Life, Ollie Johnston menjelaskan terdapat 12 prinsip animasi yang akan membuat animasi menjadi 'hidup'. Ke-12 prinsip ini meliputi solid drawing (kemampuan menggambar dan kepekaan terhadap anatomi, komposisi, berat, keseimbangan, dan pencahayaan), timing and spacing (gerak percepatan dan perlambatan), squash and stretch (pemberian efek dinamis seperti memuai dan menyusut dalam gerak sehingga benda yang mati dapat seolah hidup), anticipation (ancangancang dalam bergerak), slow in and slow out (akselerasi dan deselerasi suatu gerakan), arcs (bentuk gerak lengkung yang dihasilkan dari pergerakan benda sehingga benda tersebut tampak hidup tidak seperti gerakan robot yang patah-patah), secondary action (gerakan tambahan untuk memperkuat gerakan utama sehingga nampak lebih realistis), follow through and overlapping action (keadaan di mana suatu benda tetap bergerak sekalipun telah berhenti dan gerakan salingsilang ketika bergerak), straight ahead action and pose to pose (cara pengerjaan proses animasi), staging (peletakan karakter sehingga mendukung suasana), appeal (gaya animasi), exaggeration (mendramatisir suatu kejadian secara ekstrim) (Johnston \& Thomas, 1981).

\section{Prinsip dasar animasi}

Ada berbagai macam teori dan pendapat tentang bagaimana seharusnya animasi itu dibuat, tetapi setidaknya ada 12 prinsip yang harus dipenuhi untuk membuat sebuah animasi yang 
'hidup'. Ke-12 prinsip ini meliputi dasar-dasar gerak, pengaturan waktu, peng-kaya-an visual, sekaligus teknis pembuatan sebuah animasi.

1. Solid Drawing

Menggambar sebagai dasar utama animasi memegang peranan yang signifikan dalam menentukan, baik proses, maupun hasil sebuah animasi, terutama animasi klasik. Seorang animator harus memiliki kepekaan terhadap anatomi, komposisi, berat, keseimbangan, pencahayaan, dan sebagainya yang dapat dilatih melalui serangkaian observasi dan pengamatan, dimana dalam observasi itu salah satu yang harus dilakukan adalah menggambar.

Meskipun kini peran gambar -yang dihasilkan sketsa manual- sudah bisa digantikan oleh komputer, tetapi dengan pemahaman dasar dari prinsip 'menggambar' akan menghasilkan animasi yang lebih 'peka'.

2. Timing \& Spacing

Grim Natwick, seorang animator Disney pernah berkata, "Animasi adalah tentang timing dan spacing". Timing adalah tentang menentukan waktu kapan sebuah gerakan harus dilakukan, sementara spacing adalah tentang menentukan percepatan dan perlambatan dari bermacam-macam jenis gerak.

Contoh Timing: Menentukan pada detik keberapa sebuah bola yang meluncur kemudian menghantam kaca jendela.

Contoh Spacing: Menentukan kepadatan gambar (yang pada animasi akan berpengaruh pada kecepatan gerak) ketika bola itu sebelum menghantam kaca, tepat menghantam kaca, sesudahnya, atau misalnya ketika bola itu mulai jatuh ke lantai. Spacing (pengaturan kepadatan gambar) akan mempengaruhi kecepatan gerak bola, percepatan dan perlambatannya, sehingga membuat sebuah gerakan lebih realistis.

3. Squash \& Stretch

Squash and strecth adalah upaya penambahan efek lentur (plastis) pada objek atau figur sehingga -seolah-olah 'memuai' atau 'menyusut' sehingga memberikan efek gerak yang lebih hidup. Penerapan squash and stretch pada figur atau benda hidup (misal: manusia, binatang, creatures) akan memberikan 'enhancement' sekaligus efek dinamis terhadap gerakan/ action tertentu, sementara pada benda mati (misal: gelas, meja, botol) penerapan squash and stretch akan membuat mereka (benda-benda mati tersebut) tampak atau berlaku seperti benda hidup.

Contoh pada benda mati: Ketika sebuah bola dilemparkan. Pada saat bola menyentuh tanah maka dibuat seolah-olah bola yang semula bentuknya bulat sempurna menjadi sedikit lonjong horizontal, meskipun nyatanya keadaan bola tidak selalu demikian. Hal ini memberikan efek pergerakan yang lebih dinamis dan 'hidup'.

Contoh pada benda hidup: Sinergi bisep dan trisep pada manusia. Pada saat lengan ditarik (seperti gerakan mengangkat barbel) maka akan terjadi kontraksi pada otot bisep sehingga nampak 'memuai', hal inilah yang disebut squash pada animasi. Sedangkan stretch nampak ketika dilakukan gerakan sebaliknya (seperti gerakan menurunkan lengan), bisep akan nampak 'menyusut'.

4. Anticipation

Anticipation boleh juga dianggap sebagai persiapan/ awalan gerak atau ancangancang. Seseorang yang bangkit dari duduk harus membungkukkan badannya terlebih dahulu sebelum benar-benar berdiri. Pada gerakan memukul, sebelum tangan 'maju' harus ada gerakan 'mundur' dulu dan sejenisnya.

5. Slow in and Slow Out

Sama seperti spacing yang berbicara tentang akselerasi dan deselerasi. Slow In dan Slow Out menegaskan kembali bahwa setiap gerakan memiliki percepatan dan perlambatan yang berbeda-beda. Slow in terjadi jika sebuah gerakan diawali secara lambat kemudian menjadi cepat. Slow out terjadi jika sebuah gerakan yang relatif cepat kemudian melambat.

Contoh: Dalam gerakan misalnya mengambil gelas. Tangan akan memiliki kecepatan yang berbeda ketika sedang akan menjamah gelas, dengan ketika sudah 
menyentuhnya. Ketika tangan masih jauh dari gelas, tangan akan bergerak relatif cepat. Sedangkan ketika tangan sudah mendekati gelas, maka secara refleks tangan akan menurunkan kecepatannya (terjadi perlambatan) atau dalam konteks ini kita menyebutnya slow out.

6. Arcs

Dalam animasi, sistem pergerakan tubuh pada manusia, binatang, atau makhluk hidup lainnya bergerak mengikuti pola/jalur (maya) yang disebut Arcs. Hal ini memungkinkan mereka bergerak secara 'smooth' dan lebih realistik, karena pergerakan mereka mengikuti suatu pola yang berbentuk lengkung (termasuk lingkaran, elips, atau parabola). Pola gerak semacam inilah yang tidak dimiliki oleh sistem pergerakan mekanik/ robotik yang cenderung patah-patah.

7. Secondary Action

Secondary action adalah gerakan-gerakan tambahan yang dimaksudkan untuk memperkuat gerakan utama supaya sebuah animasi tampak lebih realistik. Secondary action tidak dimaksudkan untuk menjadi 'pusat perhatian' sehingga mengaburkan atau mengalihkan perhatian dari gerakan utama. Kemunculannya lebih berfungsi memberikan emphasize untuk memperkuat gerakan utama.

Contoh: Ketika seseorang sedang berjalan, gerakan utamanya tentu adalah melangkahkan kaki sebagaimana berjalan seharusnya, tetapi seorang animator bisa menambahkan secondary action untuk memperkuat kesan hidup pada animasinya. Misalnya, sambil berjalan 'seorang' figur atau karakter animasi mengayun-ayunkan tangannya atau bersiul-siul. Gerakan mengayun-ayunkan tangan dan bersiul-siul inilah secondary action untuk gerakan berjalan.

8. Follow Through and Overlapping Action

Follow through adalah tentang bagian tubuh tertentu yang tetap bergerak meskipun seseorang telah berhenti bergerak. Misalnya, rambut yang tetap bergerak sesaat setelah berhenti berlari.

Overlapping action secara mudah bisa dianggap sebagai gerakan saling-silang. Maksudnya, adalah serangkaian gerakan yang saling mendahului (overlapping). Pergerakan tangan dan kaki ketika berjalan bisa termasuk di dalamnya.

9. Straight Ahead Action and Pose to Pose

Dari sisi resource dan pengerjaan, ada dua cara yang bisa dilakukan untuk membuat animasi. Yang pertama adalah Straight Ahead Action, yaitu membuat animasi dengan cara seorang animator menggambar satu per satu, frame by frame, dari awal sampai selesai seorang diri. Teknik ini memiliki kelebihan: kualitas gambar yang konsisten karena dikerjakan oleh satu orang saja, tetapi memiliki kekurangan: waktu pengerjaan yang lama. Yang kedua adalah Pose to Pose, yaitu pembuatan animasi dengan cara menggambar hanya pada keyframe-keyframe tertentu saja, selanjutnya in-between atau interval antar keyframe digambar/ dilanjutkan oleh asisten/ animator lain. Cara yang kedua ini lebih cocok diterapkan dalam industri karena memiliki kelebihan: waktu pengerjaan yang relatif lebih cepat karena melibatkan lebih banyak sumber daya.

10. Staging

Seperti halnya yang dikenal dalam film atau teater, staging dalam animasi juga meliputi bagaimana 'lingkungan' dibuat untuk mendukung suasana atau 'mood' yang ingin dicapai dalam sebagian atau keseluruhan scene.

11. Appeal

Appeal berkaitan dengan keseluruhan look atau gaya visual dalam animasi. Sebagaimana gambar yang telah menelurkan banyak gaya, animasi (dan ber-animasi) juga memiliki gaya yang sangat beragam. Sebagai contoh, Anda tentu bisa mengidentifikasi gaya animasi buatan Jepang dengan hanya melihatnya sekilas. Anda juga bisa melihat ke-khas-an animasi buatan Disney atau Dreamworks. Hal ini karena mereka memiliki appeal atau gaya tertentu. 
Ada juga yang berpendapat bahwa appeal adalah tentang penokohan, berkorelasi dengan 'kharisma' seorang tokoh atau karakter dalam animasi. Jadi, meskipun tokoh utama dari sebuah animasi adalah monster, demit, siluman atau karakter 'jelek' lainnya, tetapi tetap bisa appealing.

12. Exaggeration

Exaggeration adalah upaya untuk mendramatisir sebuah animasi dalam bentuk rekayasa gambar yang bersifat hiperbolis. Dibuat untuk menampilkan ekstrimitas ekspresi tertentu, dan lazimnya dibuat secara komedik. Banyak dijumpai di film-film animasi sejenis Tom \& Jerry, Donald Duck, Doraemon, dan sebagainya.

Contoh: 1) Bola mata Tom yang 'melompat' keluar karena kaget, 2) Muka Donald yang membara ketika marah, 3) Air mata Nobita yang mengalir seperti air terjun ketika menangis.

\section{Teori Karakter Desain}

Scott McCloud dalam bukunya "Understanding Comic" menjelaskan tentang pembagian karakter-karakter desain. Karakter desain yang diciptakan memiliki pemaknaannya masingmasing sehingga dalam penggunaannya dapat sesuai dengan apa yang hendak disampaikan oleh si pembuatnya. Adapun pembagian itu dibagi menjadi:

1. Realistik

Mirip dengan kondisi aslinya di dunia nyata. Hal ini dimaksudkan untuk menyampaikan suatu informasi sedetail dan semirip mungkin dengan apa yang ada pada kehidupan nyata.

2. Ikonik

Pada pembentukan karakter ikonik, umumnya desainer bermaksud menyampaikan suatu informasi yang maknanya sama dengan realistic namun mengurangi banyak detail sehingga lebih murah diingat. Karakteristik dari karakter biasanya tidak dihilangkan sehingga menjadi suatu ciri khas atau unsur pembeda. Menurut McCloud, ikon seperti ini akan berakhir dengan Bahasa tertulis, dimana untuk detail penceritaannya dapat dimaknai dengan Bahasa tulisan bukan dengan detail yang ditampilkan pada karakter.

3. Abstrak

Bentuk, garis, dan warna saja yang digunakan sebagai symbol. Semua kemiripan dihilangkan. Umumnya, desainer ingin menyampaikan suatu makna secara tersirat sehingga membebaskan audience untuk menerjemahkannya sesuai dengan jalan pikir masing-masing.

\section{METODE PENELITIAN \\ Metode kualitatif}

Metode kualitatif merupakan penelitian yang dilakuakan untuk mengembangkan sebuah konsep yang sebelumnya sudah ada. Hasil yang diperoleh dari metode penelitian kualitatif berupa, catatan observasi, dokumen, dan juga wawancara atau angket.

Dalam riset ini, motode yang akan digunakan untuk penelitian berupa kualitatif. Seperti melakuakan observasi yang berhubungan dengan riset ini, dan juga mengumpulkan data tentang Clonomania.

\section{Teknik Pengumpulan Data \\ Teknik dokumen}

Penelitian yang dilakuakan berupa pengumpulan data dari berbagai artikel psikologi tentang kelainan mental clinomania. Sehingga penulis dapat memperoleh data dari clinomania dan informasi yang nanti akan dilanjutkan ke tahap wawancara atau konsultasi kepada psikolog.

\section{Metode wawancara}

Penelitian dilakukan dengan melakukan wawancara, penyelidikan khususnya gestur dan ekspresi secara langsung kepada orang clinomania. Dari beberapa data yang didapat dari hasil wawancara kepada psikolog dibuat beberapa catatan. Dari catatan tersebut dibuat kesimpulan 
mengenai hal-hal penting yang ada seperti gambaran visual, sifat, gestur dan penyebab seorang bisa terkena climomania yang kemudian menjadi data penting dalam perancangan penulis.

\section{Metode Perancangan}

Untuk memproduksi penelitian ini, penulis membuat pipeline dalam pembuatan agar rencana produksi tersusun dengan rapi. Metode produksi animasi ini adalah dengan teknik digital dalam bentuk animasi 3D.

\section{HASIL DAN PEMBAHASAN}

Dari beberapa riset yang diperolah mengusut tema dan konten, ada beberapa yang menjadi refrensi penulis, yang menurut penulis stlye art-nya cocok seperti environment dan faktor penyebab yang mendekati ke tema yang panulis ambil.

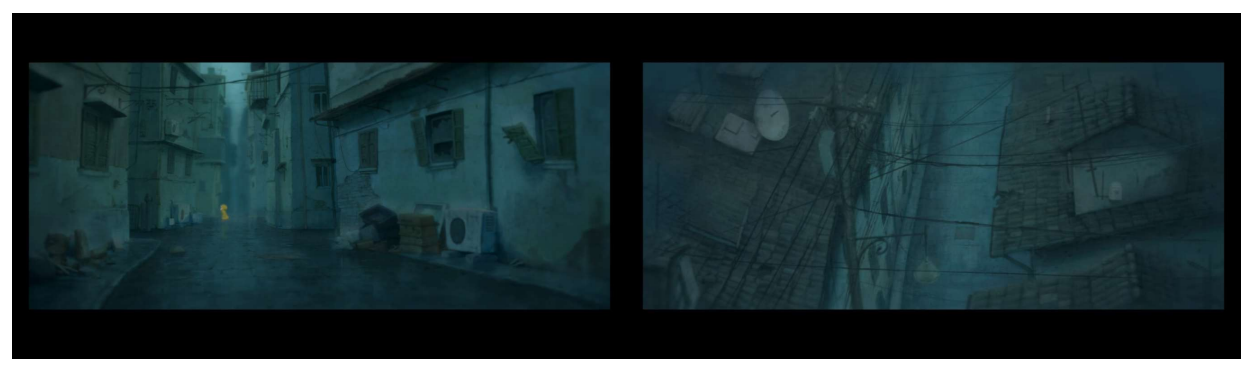

Gambar 1. RainTown

Film tersebut merupakan film animasi pendek 2D yang mengangkat tema tentang hujan di sebuah kota. Fim ini akan menjadi feferensi pembuatan 3D asset dan juga mood warna juga cocok untuk dijadikan referensi penulis untuk membuat animasi pendek.

Referensi lainnya pun digunakan, seperti film animasi pendek 3D yang berjudul Alarm yang menceritakan seseorang yang diganggu tidurnya dengan jam Alarm yang dia miliki untuk membangunkannya dan memberinya tanda untuk beraktivitas. Karakter yang ada di film animasi alarm ini mendekati dengan kriteria karakter yang penulis ingin buat untuk perancangan pembuatan animasi pendek.

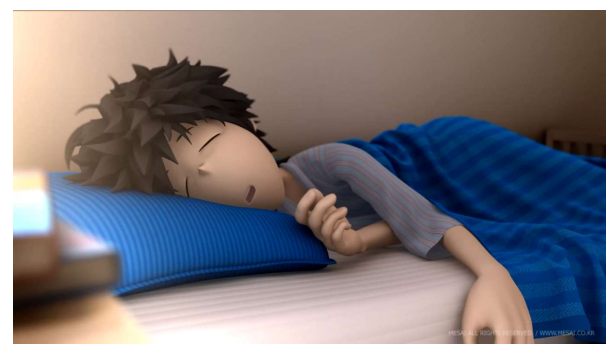

Gambar 2. Alarm

\section{Climomania}

Dari hasil riset pertama tentang climomania, penulis mengetahui dalam dunia psikologis ada beberapa kelaianan psikologis yang unik, contohnya, Climomania, terdiri dari dua kata yaitu clin dan mania. Clin sendiri berasal dari bahasa Yunani yang berarti "tempat tidur" dan mania berarti "kecanduan" atau "terobsesi". Jadi, clinomania adalah terobsesi pada tempat tidur yaitu ingin selalu berada di atas kasur atau ranjang. Obsesi pada tempat tidur tidak berarti seseorang selalu tidur, namun ia selalu ingin berada di tempat tidur walaupun sambil melakukan pekerjaan. yaitu merupakan suatu kelainan mental yang ditandai dengan keinginan yang 
berlebihan untuk berada ditempat tidur, terutama pada saat cuaca dingin. Parahnya, keinginan tak beranjak dari tempat tidur ini bisa sampai berlarut-larut.

Dari kacamata psikolog, gejala yang tampak dari seorang clinomania, ialah mereka merasa bahwa tempat tidur itu adalah surga dan tempat ternyaman. Selain itu, gejala lainnya ialah mereka tidak berinteraksi dengan orang-orang, lebih memilih untuk selalu di kamar, melakukan berbagai aktivitas di tempat tidur, dan ada masalah yang sedang dihadapi sehingga ingin merasa sendiri.

Dalam psikologi, kategori sehat mental itu ketika kita masih berinteraksi sosial. Bukan artian interaksi sosial dalam dunia maya, tetapi interaksi dalam dunia nyata seperti bertemu dengan orang lain. Clinomania akan berdampak buruk bagi pribadi seseorang jika terus-terusan tidak ingin berinteraksi di dunia nyata, menutup diri dari dunia luar, sehingga kurang bersosialisasi. Beberapa gejala penderita climonania:

1. Setelah hari panjang yang melelahkan, Anda hanya ingin ada di kasur. Tak ingin melakukan hal-hal lainnya seharian penuh.

2. Kapan pun Anda melihat tempat tidur, Anda akan merasa hangat dan sangat rindu untuk segera berbaring di atasnya.

3. Berada di atas kasur memberikan Anda kepuasan yang tak terhingga.

4. Ada perasaan meledak-ledak dan tak terhingga saat Anda berada di atas kasur.

5. Ada perasaan yang sangat malas dan tak ingin bergerak sama sekali. Rasanya tak ingin terpisah dari kasur. Sama halnya seperti yang dirasakan saat jatuh cinta.

6. Kerinduan yang sangat pada tempat tidur terkadang membuat Anda bisa jadi lebih menghargai tempat tidur dibanding yang lain, bahkan orang lain dalam hidup.

7. Tempat tidur adalah satu-satunya tempat di mana Anda menumpahkan semua isi hati dan merasa nyaman setelahnya.

8. Anda ingin menghabiskan banyak waktu di atas kasur. Mulai tidur, makan, bermain, nonton tv, bahkan bekerja.

9. Anda tak peduli ketika tak bisa jadi bagian dari komunitas sosial, asalkan Anda bisa tetap berada di kasur.

10. Anda punya pikiran kalau kasur Anda tidak ingin Anda beranjak darinya.

11. Atau, Anda berpikiran kalau kasur membutuhkan Anda lebih dari Anda butuh kasur.

12. Alarm tak mempan untuk membangunkan Anda dari kasur. Sekalipun Anda sudah punya rencana untuk bangun awal, namun masih saja ada alasan untuk bertahan lebih lama di kasur.

13. Ketika kasur sudah bisa membuat Anda nyaman, tak peduli lagi dengan hal lain.

14. Beranjak dari tempat tidur bisa membuat Anda menyesal ketika aktivitas yang dilakukan tak memuaskan. Lebih baik tidur.

15. Tidur atau berada di kasur adalah jawaban pertama Anda ketika ditanya tentang hobi.

Dari wawancara penulis dengan salah satu narasumber psikologi, climomania adalah gangguran psychological yang termasuk gangguran psychological salah satunya yang termasuk ke dalam katagori mania atau gangguan mood atau bipolar. Menurut psikolog yang penulis wawancarai, orang mengalami climomania bisa dikarenakan depresi atau tertekan dengan masalah yang dihadapi sehingga climomnaia bisa juga mengganggu aktivitas yang penting bagi seorang climomnia, tetapi bukan berarti seorang climomania tidak benar-benar beraktivitas, hanya saja banyak hal penting yang sudah dilewatkan. dan juga susah untuk berinteraksi dengan orang, yang akan menjadi susah untuk bersosialisasi pada lingkungannya, dan itu akan berlangsung cukup lama. Dari hasil wawancara juga, climomania bisa terjadi bukan hanya di tempat tidur saja, tetapi juga bisa di tempat lain seperti sofa, itu bergantung senyamannya orang yang mengalami climomania tersebut.

Pemicu bisa terjadinya climomania, bisa juga terjadi karena suasana atau atmosfir lingkungan yang mendukung seperti pada saat cuaca sedang dingin, turun hujan atau sedang mendung, dan juga bisa dikarenakan stress yang membuat seseorang climomania. Kehilangan minat dan kegembiraan dan berkurangnya energi yang menuju meningkatnya mudah lelah. 
Climomania juga mepunyai tahap atau tingkat keparahan, kalau masih dalam tahap rendah, dari hasil wawancara, mungkin hanya tidur-tiduran seharian atau sekitar dau hari sampai tiga hari, kalau sudah ke tahap yang paling parah sampai mengganggu aktivitas yang penting, itu bisa terjadi hingga sampai seminggu atau sebulan. Ciri-ciri awal seseorang bisa terkena climomania biasanya setelah mengalami hari panjang yang melelahkan, sehingga perasaannya sangat ingin capat-cepat langsung berbaring di kasur, walaupun sedang berada di luar rumah.

Mania (dari bahasa Yunani mainomai yang artinya menjadi marah dan geram) adalah sebuah kondisi tekanan medis yang dikarakteri oleh tingkat mood, tenaga, pola pemikiran yang tidak biasa dan terkadang kejiwaan. Ada beberapa kemungkinan yang menyebabkan seseorang menderita mania termasuk penyalahgunaan obat dan tumor otak, tetapi paling banyak dikarenakan kelainan bipolar, di mana hidup awal mania digantikan oleh bagiannya yang depresi berat. Mania terbagi berdasarkan kekuatan pengaruhnya, mulai dari mania sedang (dikenal juga sebagai hypomania) hingga mania penuh dengan ciri-ciri kegilaan sehingga gestur seorang climomania seperti orang yang malas gerak atau berbuat sesuatu yang lebih penting, tetapi bedanya seorang climomania masih melakuakan aktivitas walaupun di tempat tidur dan jarang keluar rumah.

\section{Penulisan Judul}

Untuk penulisan judul atau title, penulis mangguanakan font Claire Hand terlihat memiliki garis dan lekukan di font tersebut yang membuat terkesan malas atau mengantuk. Dan juga tulisan MOOD menggambarkan seseorang yang malas untuk beranjak dari posisi atau tempat ternyamannya yang dia tempati dan itu pas dan sesuai dengan Climomania tema yang akan di angkat ke dalam film animasi pendek ini. Dilihat dari desain font tersebut, ada background air hujan yang menendakan seorang climomania lebih sering terjadi karena turun hujan dan juga terdapat gambar bantal yang menyimbolkan seorang yang terobsesi terhadap tempat tidur atau malas bangun dari tempat tidur nya (climomania).

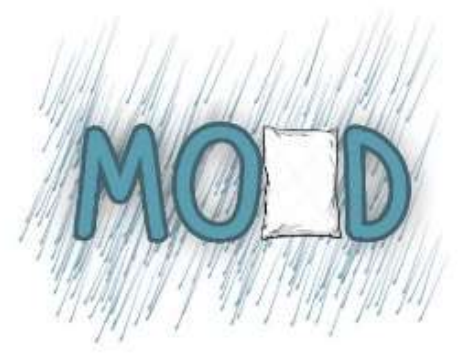

Gambar 3. Judul

\section{Markus (remaja dewasa)}

Markus adalah seorang perja kantoran berumur 25 tahun yang baru saja depresi karena masalah percintaan. Saking depresinya dia hanya mengurung dirinya di kamar seharian bahkan berhari-hari. Kegiatan selama dia mngurung diri di kamar hanya tidur-tiduran, dan menonton tv. Karena kegiatan itulah markus mengidap ganguan psikologis climomania yang membuat dirinya melihat dunia hanya sebesar kamar atau apartement-nya sehingga dia sulit untuk bersosialisai atau berinteraksi dengan orang banyak. 


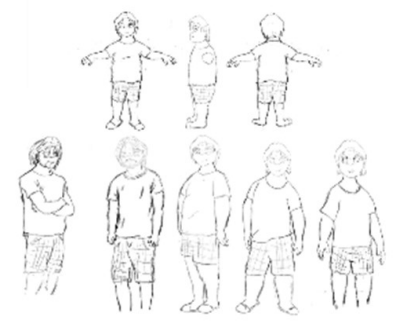

Gambar 4. Karakter Markus

\section{Margaret (mantan pacar)}

Margaret adalah sosok yang membuat markus menjadi depresi, karena Margaretlah yang memutuskan hubungan antara mereka berdua. Sebenarnya Margaret hanya tampil di bingkai foto di kamar markus untuk dikenang dan setelah markus baru putus hubungan dengan Margaret, dia hanya dilihat dengan ekspresi sedih dari markus.

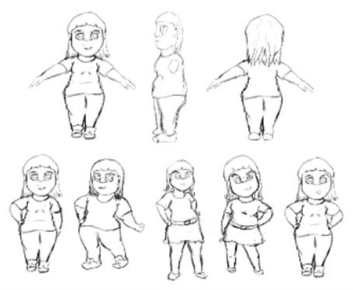

Gambar 5. Karakter Margaret

\section{Tema climomania}

Karena mengusung tema climomania, seperti envi akan banyak di daerah perkotaan dengan cuaca yang sedang turun hujan dan di dalam kamar yang kotor banyak barang berantakan di mana-mana. Untuk envi perkotaannya sendiri akan bertempat di sekitar pemukinan warga, dan envi kamarnya berlokasi di apartement atau tempat kost di pinggir jalan raya. Dan juga warna dari envi juga mngusung warna yang lebih ke cold atau ke arah yang lebih gelap di karenakan sedang turun hujan. Dan pendekatan style yang di pilih cenderung ke realist dengan warna dan texture yang agak gelap dan kotor.
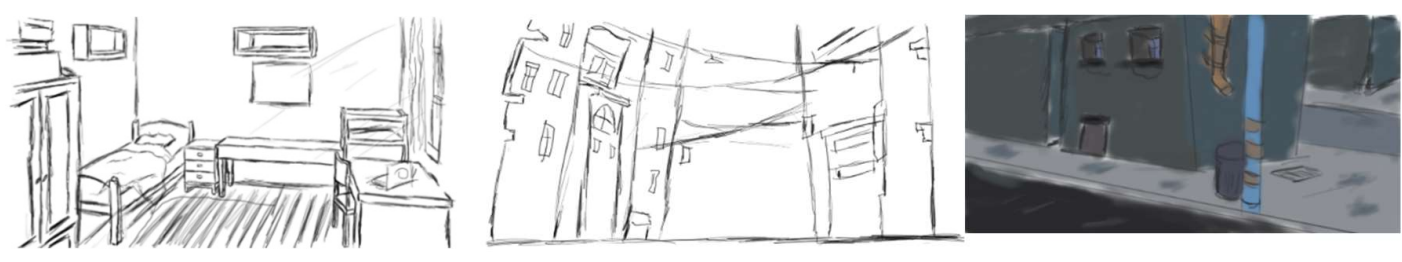

Gambar 6. Latar 


\section{Story Style}

Cerita pada animasi ini lebih menonjolkan kepada gerakan dan tingkah laku penderita climomania yang nantinya dari sudut pandang karakter utama akan bercerita mengenai climomania, seperti pertama awal terkena depresi, kegiatan yang dia lakukan sehari-hari sampai si penderita sadar bahwa dunia itu luas, bukan hanya berada di dalam kamar dan melakuakan kegiatan tidak penting yang nantinya merugikan diri sendiri.

\section{Visual Style}

Dari environment-nya mungkin akan sedikit di exaggerate dan berwarna agak gelap dengan dibarengi turunnya hujan yang nanti akan memberikan kesan aneh, asing dan juga mencerminkan sedih dan muram dari setting yang akan menjadi lokasi karakter. Texture yang akan digunakannya pun akan menggunakan texture realist dan juga beberapa envi akan mengguanakan texture flat color.

\section{SIMPULAN}

Dalam pembuatan sebuah animasi pendek banyak aspek yang harus diperlihatkan mulai dari segi konsep, segi cerita, karakter dan juga environment yang nantinya akan digabung ke sebuah animasi pendek. Karena dalam pembuatan animasi ini harus memiliki konsep dan materi yang matang dan juga eksekusi yang baik menjadi faktor penting untuk membuat animasi pendek ini. Dengan begitu dibutuhkan riset dari konsep yang ingin di buat ke dalam sebuah film animasi pendek. Seperti animasi yang akan penulis buat mengusung tema tentang climomania sehingga bercerita lebih menonjolkan ke arah gestur dan tingkang laku penderita climomania. yang akan menjadi sulit jika tidak memiliki data yang lengkap mengenai climomania untuk membuat climomania tersebut. Sehingga karakter dan juga plot yang akan penulis bawa ke dalam animasi pendek ini, lebih cenderung sedih dan muram dikarenakan climomania sendiri terjadi karena depresi.

\section{DAFTAR PUSTAKA}

Clinomania, orang yang susah lepas dari kasur saat hujan. (9 Februari 2015). https://www.cnnindonesia.com/gaya-hidup/20150209101349-255-30586/clinomaniaorang-yang-susah-lepas-dari-kasur-saat-hujan/

Johnston, O., \& Thomas, F. (1981). The illusion of life: Disney animation (p. 576). New York: Disney Editions.

Kenali gejala clinomonia. (8 April 2017). http://fresh.suakaonline.com/kenali-gejala-clinomania/

Prayogo, R. F. (2015). Illuminati dalam karakter minion pada film despicable me i dan despicable me 2 (Studi Semiotik Roland Barthes Tentang Illuminati Dalam Karakter Minion) (Doctoral dissertation, Stikosa-AWS).

Shaw, S. (2012). Stop motion: craft skills for model animation. Taylor \& Francis.

Wright, J. A. (2015). Animation writing and development. Burlington. 